\title{
Foreground Extraction pada Citra Daun Melon dengan Bantuan Deep Neural Network
}

\author{
Muhammad Fajar Estu Nugroho', Nurlana Sanjaya ${ }^{2}$, Ayu Shafira Tubagus ${ }^{3}$, \\ M Rayhan Rizqullah Syarif ${ }^{4}$, Chaerur Rozikin ${ }^{5}$ \\ 1,2,3,4,5 Teknik Informatika, Fakultas Ilmu Komputer, Universitas Singaperbangsa Karawang \\ ${ }^{1}$ fajar.estu17147@student.unsika.ac.id, ${ }^{2}$ nurlana.sanjaya17167@ student.unsika.ac.id, \\ ${ }^{3}$ ayu.shafira17064@ student.unsika.ac.id, ${ }^{4}$ m.rayhan17012@student.unsika.ac.id, \\ ${ }^{5}$ chaerur.rozikin@staff.unsika.ac.id
}

\begin{abstract}
Abstrak
Ekstraksi fitur merupakan tahapan dalam melakukan proses pengolahan citra. Ada banyak metode ekstraksi fitur yang dilakukan untuk proses pengolahan citra, salah satunya adalah ekstraksi foreground. Ekstraksi foreground yang merupakan segmentasi pada gambar diperlukan untuk memisahkan obyek utama pada citra yang akan diproses dalam pengolahan citra diperlukan untuk menyeleksi obyek utama dengan background-nya sehingga proses pengolahan citra bisa berfokus pada obyek utama. Ada berberapa algoritma yang bisa diterapkan untuk melakukan ekstraksi foreground, salah satu yang paling popular adalah algoritma Grabcut. Di dalam jurnal ini, kami mencoba melakukan ekstraksi foreground pada obyek daun melon sebagai obyek utama dengan harapan hasil dari ekstraksi foreground dapat lebih lanjut dimanfaatkan terutama dalam proses pengembangan aplikasi yang berhubungan dengan daun melon, seperti misalnya pendeteksian dini terhadap penyakit daun melon berbasis citra. Dalam jurnal ini ekstraksi foreground dilakukan dengan bantuan algoritma Grabcut dengan bantuan deep neural network yang didasarkan pada algoritma holistically-nested edge detection dan diaplikasikan sekaligus pada data obyek daun melon yang banyak. Algoritma yang diusulkan bertujuan untuk meningkatkan akurasi dari grabcut dan tetap menjaga user input dengan seminimal mungkin. Dengan melakukan pengujian berdasarkan pengujian kasus yang dibuat, hasilnya pada pengujian sebanyak 351 citra daun melon, terdapat $68 \%$ citra yang dapat diekstraksi citra daunya dengan sempurna.
\end{abstract}

Kata kunci : Deep Neural Network, Grabcut, Ekstraksi Foreground

\section{Pendahuluan}

Melon (Cucumis melo L) merupakan tanaman holtikultura yang biasa ditanam di dalam rumah kaca merupakan tanaman penting di seluruh dunia (Huang et al., 2017). Dalam proses penanamanya, tanaman melon tidak terlepas dari penyakir baik dari virus maupun dai bakteri. Salah satu bagian tanaman yang dapat terkena penyakit adalah daun. Dalam (Pineda et al., 2018) deteksi awal dari penyakit daun pada melon dapat menggunakan deteksi menggunakan data gambar. Tentunya data gambar yang digunakan harus diolah dahulu dengan pengolahan citra digital sehingga pemrosesan dapat berfokus hanya pada daun.

Pengolahan citra digital memiliki beberapa tujuan, salah satunya untuk mengambil ciri dari citra sehingga dapat dikenali yang biasa disebut dengan ekstraksi ciri (Riantama et al., 2019). Ekstraksi fitur (feature extraction) adalah suatu metode yang digunakan untuk mengambil ciri objek pada suatu citra dengan tujuan mengenali objek tersebut (Suryawibawa et al., 2015). Salah satu tahapan dalam ekstraksi fitur adalah akuisisi yaitu sebuah proses mendapatkan data citra dari analog ke bentuk digital (Wirdiani et al., 2018). Pemisahan background dari foreground menjadi hal penting dalam pemrosesan aplikasi berbasis computer vision (V et al., 2020).

Pengambilan fitur foreground dapat dilakukan dengan pendekatan algoritma GraphCut. Sebuah algoritma yang secara efisien memisahkan background dengan foreground (Yi \& Moon, 2012). Namun algoritma Grabcut lalu muncul sebagai pengganti algoritma GraphCut dengan kelebihan kelebihan yang disediakan oleh Grabcut (Boykov \& Jolly, 2001). Sehingga untuk pendekatan selanjutya adalah dengan metode Grabcut, sebuah algoritma foreground extraction dimana pengguna memberikan input berupa citra disertai dengan daerah foreground yang dipilih menggunakan memberikan bounding box yang menunjukkan area lokasi pasti foreground atau dengan mask yang menunjukkan foreground dan background dan kemudian algoritma akan memisahkan foreground dari background (Rother et al., 2004). Grabcut merupakan algoritma populer untuk melakukan segmentasi pada gambar dengan 
mengurangi kebutuhan input dari pengguna (Li et al., 2018). Namun algoritma ini mempunyai kecepatan yang relatif lambat dan memiliki keterbatasan ketika objek background terlalu kompleks (Li et al., 2018). Dalam (Riantama et al., 2019) menggunakan 40 buah citra dan dilakukan pengujian sebanyak 3 kali iterasi untuk mendapatkan waktu rata-rata proses segmentasi citra. Citra hasil segmentasi tidak selalu bersih dari noise atau bagian dari background karena piksel warna berada di dalam daerah bounding box dianggap sebagi bagian foreground. Grabcut juga memiliki keterbatasan untuk citra dengan kontras yang rendah (Aykut \& Akturk, 2018).

Pendekatan selanjutnya adalah dengan algoritma canny edge dengan menganalisis tepi dari objek (Canny, 1986) untuk mendapatkan bagian foreground dari citra. Algoritma canny edge pada dasarnya menemukan titik tepi pada gambar grayscale dengan perubahan nilai intensitas gradien yang paling besar, daerah ini ditemukan dengan menentukan gradien pada gambar (Kaehler \& Gary, 2008). Tepi adalah perubahan nilai intensitas derajat keabuan yang besar dalam jarak yang singkat. Deteksi tepi juga merupakan algoritma fundamental dalam pengolahan citra, machine vision, dan computer vision (Umbaugh, 2010). Namun algoritma canny edge memiliki berberapa kelemahan diantaranya adalah tidak mampunya memisahkan background dan target deteksi tepi (Xuan \& Hong, 2018) dalam berberapa kasus dimana setiap objek memiliki kontras yang hampir serupa dan hysteresis thresholding yang diperlukan dalam algoritma ini membutuhkan proses manual yang membutuhkan percobaann ulang dan membutuhkan validasi secara visual. Masalah selanjutnya dengan hysteresis thresholding yang membutuhkan dua variabel threshold, yaitu minimum value dan maximum value dimana jika intensitas gradien lebih dari maximum value maka ditentukan menjadi sebuah tepi dan intensitas gradien dibawah minimum value ditentukan sebagai bukan tepi (Kaehler \& Gary, 2008), adalah setiap gambar membutuhkan threshold yang berbeda - beda sehingga perbedaan pencahayaan juga membutuhkan threshold yang berbeda juga (Xie \& $\mathrm{Tu}$, 2015). Hysteresis Thresholding dijelaskan melalui gambar 1.

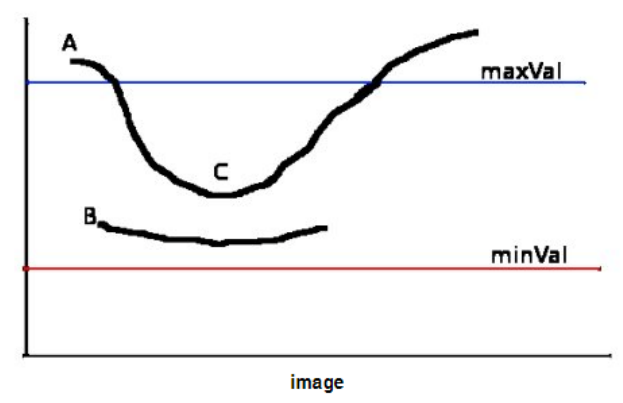

Gambar 1 Hysteresis Thresholding (OpenCV, n.d.) Dalam (Xie \& Tu, 2015) peneliti mencoba memberikan inovasi deteksi tepi dengan deep neural network untuk menghasilkan deteksi tepi yang lebih baik. Algoritma tersebut disebut Holistically-Nested Edge Detection (HED) yang bisa menjadi pendekatan untuk melakukan deteksi foreground pada jurnal ini. Tujuan mendeteksi tepi sendiri adalah untuk melakukan segementasi pada bagian - bagian pada citra. Dengan bantuan adanya deep neural network, yaitu algoritma pemodelan tingkat tinggi pada data dengan fungsi transformasi non-linear yang tertata dengan berlapis - lapis (Deng \& Yu, 2013) yang diterapkan pada deteksi tepi, penelitian ini berfokus pada proses ekstraksi foreground dan diharapkan algoritma deteksi tepi menggunakan bantuan HED dapat lebih baik dalam melakukan deteksi tepi dan dapat memisahkan antara foreground dengan background dengan lebih baik dibanding jika hanya menggunakan algoritma Grabcut. Citra daun dipilih sehingga penelitian kedepanya dapat menggunakan algoritma dalam jurnal ini untuk mengekstraksi fitur - fitur pada daun dan menggunakanya seperti untuk deteksi penyakit pada daun berbasis computer vision.

\section{Metode Penelitian}

Tahapan metode penelitian yang dilakukan sama dengan tahapan pengolahan citra digital pada umumnya. Metodologi penelitian dimulai dari pengumpulan data, perancangan algoritma dan pengujian.

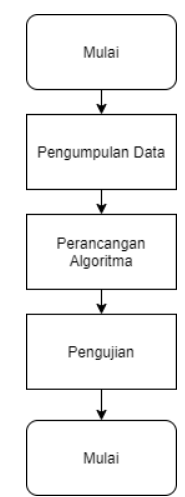

Gambar 2 Metodologi Penelitian

\subsection{Pengumpulan Data}

Data yang digunakan adalah data berupa gambar citra daun melon yang diambil dari kebun kebun melon yang berada di Purwakarta dan Karawang. Data gambar berasal dari tanaman tanaman dengan kondisi yang bervariasi mulai dari yang sehat sampai yang sakit dengan posisi pengambilan gambar yang berbeda - beda. Gambar diambil sendiri oleh peneliti pada tahun 2019 menggunakan kamera handphone.

\subsection{Perancangan Algoritma}

Untuk melakukan ekstraksi foreground dengan deep neural network, dibutuhkan bahasa pemograman yang lengkap dari segi fitur dan pustakanya. Dengan pustaka OpenCV, Python 
menjadi bahasa yang dipilih untuk melakukan uji coba algoritma. Sebelum melakukan penulisan program, algoritma terlebih dahulu digambar menggunakan flowchart diagram untuk kemudahan penulisan program.

\subsubsection{Algoritma Program Keseluruhan}

Program secara keseluruhan akan menggabungkan antara algoritma grabcut dengan algoritma HED. Gambar 2, menunjukkan proses kerja dari program yang diusulkan secara keseluruhan.

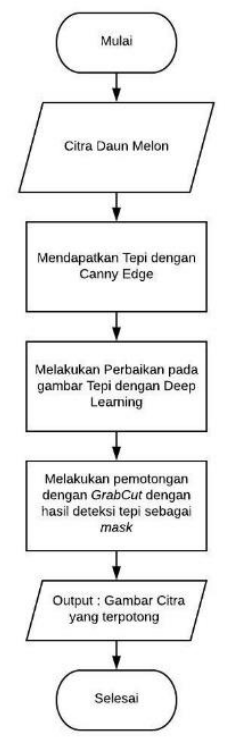

Gambar 3 Flowchart Diagram untuk Algoritma Ekstraksi Foreground

Proses dari program secara keseluruhan adalah sebagai berikut :

1. Muat gambar yang akan diproses

2. Lakukan deteksi tepi sederhana dengan canny edge untuk melakukan perbandingan kesuksesan ekstraksi foreground dengan HED

3. Hasil dari deteksi tepi akan diperbaiki menggunakan holistically-nested edge detection (Xie \& Tu, 2015).

4. Hasil dari perbaikan tadi akan dijadikan sebagai mask untuk digunakan ke dalam grabcut.

Program akan mengeluarkan output berupa gambar yang telah terseleksi foreground-nya.

\subsubsection{HED Untuk Deteksi Tepi}

Sebelum memasuki tahap Grabcut, mask dari gambar dibutuhkan untuk menentukan batas - batas antara foreground dan background. Mask dihasilkan dengan menentukan garis tepi dari citra menggunakan HED. Gambar 3, Menunjukkan flowchart pengaplikasian HED terhadap citra.

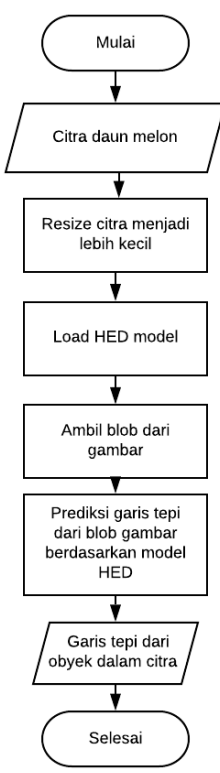

Gambar 4 Flowchart deteksi tepi dengan HED

Proses deteksi tepi dengan model HED dijelaskan sebagai berikut :

1. Masukkan citra daun melon.

2. Lakukan resize terhadap citra untuk menghemat memori.

3. Muat HED model. HED model adalah model pre-trained yaitu model pendeteksian garis tepi yang dibuat menggunakan deep neural network. Model ini digunakan untuk melakukan prediksi dan deteksi terhadap garis tepi objek - objek pada gambar.

4. Ambil blob image.

5. Melakukan prediksi terhadap garis tepi berdasarkan model HED yang sudah dilatih sebelumnya.

6. Output berupa gambar garis tepi yang nantinya akan menjadi mask untuk melakukan Grabcut.

\subsubsection{Algoritma Grabcut}

Algoritma Grabcut digunakan untuk mengekstraksi foreground dari background.

Berikut ini adalah penjelasan dari algoritma grabcut dari gambar 5 :

1. Masukkan citra yang akan diolah

2. User menentukan foreground dan background. Penentuan bisa menggunakan masukkan zona foreground dalam bentuk koordinat atau mask.

3. Gaussian Mixture Model (GMM) akan memodelkan foreground dan background.

4. GMM akan melakukan clustering terhadap piksel - piksel untuk menentukan foreground dan background.

5. Dari distribusi piksel, dibuat grafik.

6. Dengan Algoritma mincut, grafik disegmentasi untuk memisahkan antara piksel dari foreground dengan background. 


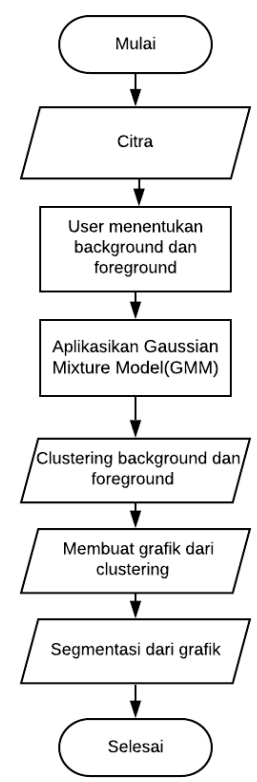

Gambar 5 Algoritma Grabcut

\subsubsection{Penerapan Algoritma Grabcut}

Algoritma Grabcut membutuhkan variabel utama citra dan mask untuk memisahkan foreground dan background. Mask merupakan citra abu - abu dengan derajat keabuan berbeda - beda di setiap daerahnya untuk menentukan mana foreground dan background. Mask didapatkan dari algoritma HED. Gambar 5, Menunjukkan flowchart dari penerapan algoritma Grabcut dengan mask dari HED.

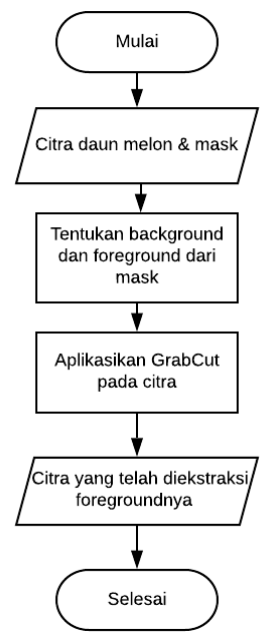

Gambar 6 Penerapan Algoritma Grabcut dengan Mask

Penjelasan dari flowchart dari gambar 5 adalah sebagai berikut :

1. Masukkan citra daun melon dan mask hasil HED

2. Tentukan bagian foreground dan background dari mask. Dalam tulisan ini digunakan probable foreground dan probable background untuk melakukan pemisahan [17], penentuan probable foreground menggunakan daerah mask yang mempunyai derajat keabuan kurang dari sama dengan 50 dan daerah mask dengan derajat keabuan lebih dari sama dengan 205 sebagai background.

3. Aplikasikan Grabcut pada citra.

4. Output berupa citra yang telah dilakukan Grabcut.

\subsection{Pengujian}

Pengujian menggunakan uji berupa test case untuk menguji kemampuan program dalam mengekstraksi foreground dari background.

\section{Hasil dan Pembahasan}

\subsection{Perisapan Data}

Data uji coba menggunakan data citra daun melon yang diambil dari kebun - kebun yang belokasi di Purwakarta dan Karawang. Data yang digunakan terdapat 351 data gambar yang terdiri dari berbagai macam bentuk dan kondisi daun melon mulai dari yang sakit hingga yang sehat, dari yang berwarna hijau hingga kekuningan karena penyakit. Semua data gambar dimasukkan ke dalam sebuah folder dan nantinya akan dilakukan proses ekstraksi foreground secara looping untuk setiap gambar di dalam folder.

\subsection{Detail Pelaksanaan}

Sebuah test case dibuat untuk menentukan hasil dari uji coba. Test case tersebut terdiri dari 4 kasus sebagai berikut :

1. Memotong Sempurna

Algoritma berhasil melakukan pemotongan dengan sempurna dan berhasil mendeteksi tepian dari daun melon dengan rasio luas daun yang terpotong dengan luas daun pada gambar aslinya antara $80 \%-100 \%$ dan tidak menyisakan obyek background.

2. Hampir Memotong Sempurna

Algoritma berhasil mendeteksi dan melakukan pemotongan pada obyek daun, namun ada berberapa obyek lain yang ikut terdeteksi sebagai daun dengan rasio luas daun yang terpotong dengan luas daun pada gambar aslinya antara 60\% - 79\% atau menyisakan obyek background dengan rasio kurang dari atau sama dengan $20 \%$.

3. Banyak Salah Memotong

Algoritma mendeteksi dan memotong obyek daun namun ada banyak obyek lain yang terdeteksi sebagai daun dengan rasio luas daun yang terpotong dengan luas daun pada gambar aslinya antara 30\% - 59\% atau menyisakan obyek pada background dengan rasio kurang dari atau sama dengan $50 \%$.

4. Salah Memotong

Algoritma gagal mendeteksi dan memotong obyek daun dengan rasio foreground yang 
terekstraksi kurang dari $30 \%$ atau obyek background yang terbawa lebih dari $50 \%$.

Gambar 6 menunjukkan sampel dari test case yang menunjukkan contoh dari kasus - kasus yang ditemukan dalam pengujian dari kiri ke kanan; memotong sempurna, hampir memotong sempurna, banyak salah memotong, salah memotong.

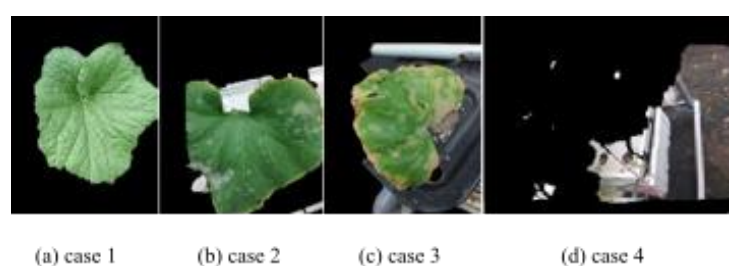

Gambar 7 Contoh Kasus Hasil Pengujian

\subsection{Hasil Pengujian}

Algoritma Holistically-Nested Edge Detection memiliki hasil deteksi tepi lebih baik dai algoritma canny edge karena dapat dengan jelas memperlihatkan batas - batas dari setiap obyek dengan baik. Gambar 7 menunjukkan perbandingan antara hasil deteksi tepi dengan canny edge dengan algoritma HED. Dari kiri ke kanan ; Hasil deteksi tepi dengan canny edge, hasil deteksi tepi dengan HED.

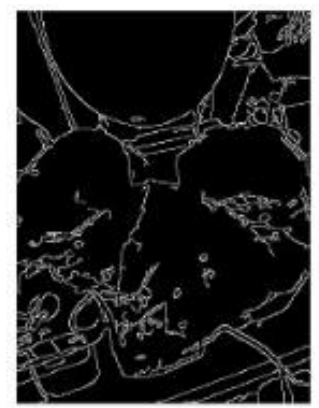

(a) canny edge

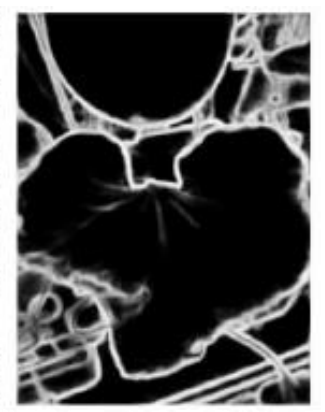

(b) HED
Gambar 8 Hasil Deteksi Tepi

Hasil dari deteksi tepi dengan HED selanjutnya dijadikan sebuah mask untuk melakukan operasi algoritma Grabcut. Pada penelitian ini kami memiliki 351 Citra Daun Melon yang sehat dan memiliki penyakit. Dengan algoritma Grabcut yang menggunakan mask dari hasil deteksi tepi, menunjukkan adanya peningkatan dari hasil ekstraksi foreground. Gambar 8 menunjukkan perbandingan antara gambar awal, hasil pemotongan dengan Grabcut, dan hasil pemotongan dengan algoritma Grabcut dengan bantuan deteksi tepi dengan model HED. Dari kiri ke kanan; Gambar Awal, Hasil Grabcut Tanpa Bantuan HED, Hasil Grabcut dengan Deteksi Tepi Menggunakan Bantuan HED.

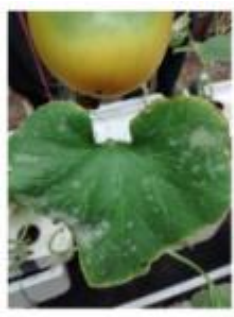

(a) citra awal

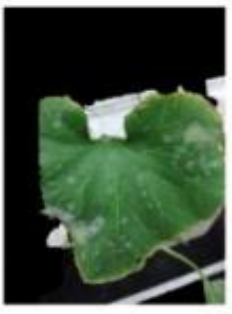

(b) Grabcut

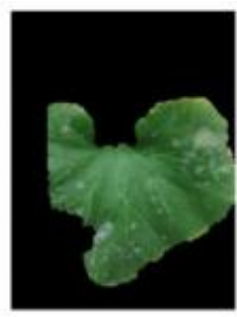

(c) Grabcut + HED
Gambar 9 Sampel Citra Hasil dari Pemotongan

Data - data hasil pengujian dimasukkan ke dalam tabel pada software Microsoft Excel. Hasilnya, dengan bantuan deep learning, persentase case ke 1 yaitu memotong sempurna mencapai $68 \%$ Dengan bantuan mask dari deteksi tepi menggunakan HED, algoritma Grabcut dapat lebih baik dalam membedakan foreground dan background. Tabel 1, menunjukkan hasil perbandingan hasil pengujian dengan bantuan deep neural network dan hanya menggunakan Grabcut.

Tabel 1 Hasil Pengujian

\begin{tabular}{cccc}
\hline \multicolumn{2}{c}{$\begin{array}{c}\text { Dengan Deep Neural } \\
\text { Network }\end{array}$} & \multicolumn{2}{c}{$\begin{array}{c}\text { Hanya Menggunakan } \\
\text { Grabcut }\end{array}$} \\
\hline Case & Persentase & Case & Persentase \\
\hline $\mathbf{1}$ & $68 \%$ & 1 & $29 \%$ \\
\hline $\mathbf{2}$ & $0 \%$ & 2 & $18 \%$ \\
\hline $\mathbf{3}$ & $8 \%$ & 3 & $44 \%$ \\
\hline $\mathbf{4}$ & $25 \%$ & 4 & $9 \%$ \\
\hline
\end{tabular}

Persentase case 1 dimana hasil pemotongan lebih halus dan lebih baik dalam memotong daun, lebih banyak pada pengujian dengan bantuan HED.

\section{Kesimpulan}

Ekstraksi foreground pada objek daun melon dengan bantuan algoritma deteksi tepi HolisticallyNested Edge Detection telah dilakukan dalam jurnal ini. Dari hasil penelitian yang dilakukan, akurasi dari penggunaan Grabcut dengan Deep Neural Network HED untuk melakukan pemisahan background dan foreground pada citra daun melon telah dilakukan dengan tingkat akurasi mencapai 68\%. Meskipun tingkat akurasi kesuksesan hanya mencapai $68 \%$, namun algoritma ini bisa digunakan karena lebih baik menyeleksi foreground daripada Grabcut dan bisa digunakan untuk proses ekstraksi foreground untuk data yang banyak karena algoritma ini membutuhkan user input minimal. Kesuksesan dari pemisahan antara background dan foreground dipengaruhi oleh pencahayaan dan kontras antara foreground dan background. Harapan untuk penelitian selanjutnya dapat meningkatkan kemampuan algoritma untuk mendeteksi objek lain, tidak hanya terbatas pada daun melon dan mendapatkan tingkat ke akurasi yang lebih tinggi dari penelitian saat ini. 


\section{Daftar Pustaka:}

Aykut, M., \& Akturk, S. M. (2018). An Improvement on Grabcut with CLAHE for the Segmentation of the Objects with Ambiguous Boundaries. Image Analysis and Recognition, 116-122. https://doi.org/10.1007/978-3-31993000-8_14

Boykov, Y. Y., \& Jolly, M.-P. (2001). Interactive Graph Cuts for Optimal Boundary \& Region Segmentation of Objects in N-D Images. Internation Conference on Computer Vision, July, 105-112.

Canny, J. (1986). A Computational Approach to Edge Detection. IEEE Transactions on Pattern Analysis and Machine Intelligence, 8(6), 679698. https://doi.org/10.1109/TPAMI.1986.4767851

Deng, L., \& Yu, D. (2013). Deep learning: Methods and applications. Foundations and Trends in Signal Processing, 7(3-4), 197-387. https://doi.org/10.1561/2000000039

Huang, Y., Li, W., Zhao, L., Shen, T., Sun, J., Chen, H., Kong, Q., Nawaz, M. A., \& Bie, Z. (2017). Melon fruit sugar and amino acid contents are affected by fruit setting method under protected cultivation. Scientia Horticulturae, 214, 288-294. https://doi.org/10.1016/j.scienta.2016.11.055

Kaehler, A., \& Gary, B. (2008). Learning OpenCV--Computer Vision with the OpenCV Library. In IEEE Robotics \& Automation Magazine (Vol. 16, Issue 3). O’Reilly Media, Inc. https://doi.org/10.1109/mra.2009.933612

Li, Y., Zhang, J., Gao, P., Jiang, L., \& Chen, M. (2018). Grab Cut Image Segmentation Based on Image Region. 2018 IEEE 3rd International Conference on Image, Vision and Computing (ICIVC), 311-315. https://doi.org/10.1109/ICIVC.2018.8492818

OpenCV. (n.d.). Canny Edge Detection. https://docs.opencv.org/master/da/d22/tutorial _py_canny.html

Pineda, M., Pérez-Bueno, M. L., \& Barón, M. (2018). Detection of bacterial infection in melon plants by classification methods based on imaging data. Frontiers in Plant Science, 9(February), 1-10. https://doi.org/10.3389/fpls.2018.00164

Riantama, G. N. S., Piarsa, I. N., \& Sasmita, G. M. A. (2019). Pengaruh Segmentasi Terhadap Hasil Rotasi Citra Menggunakan Metode Minimum Area Rectangle. Jurnal Ilmiah Merpati (Menara Penelitian Akademika Teknologi Informasi), 7(2), 95-102. https://doi.org/10.24843/JIM.2019.v07.i02.p01

Rother, C., Kolmogorov, V., \& Blake, A. (2004). Grabcut - Interactive foreground extraction using iterated graph cuts. ACM SIGGRAPH 2004 Papers, SIGGRAPH 2004, 309-314. https://doi.org/10.1145/1186562.1015720

Suryawibawa, I. W. A., Putra, I. K. G. D., \& Wirdiani, N. K. A. (2015). Herbs Recognition Based on Android using OpenCV. International Journal of Image Graphics and Signal Processing, 2(January), 1-7. https://doi.org/10.5815/ijigsp.2015.02.01

Umbaugh, S. E. (2010). Digital Image Processing and Analysis: Human and Computer Vision Applications with CVIPtools, Second Edition 2nd Edition. CRC Press.

V, R., K, N., \& J, I. R. (2020). Foreground algorithms for detection and extraction of an object in multimedia. International Journal of Electrical and Computer Engineering, 10(2), 1849-1858.

https://doi.org/10.11591/ijece.v10i2.pp18491858

Wirdiani, N. K. A., Sukma, S., Sudana, O., \& Wibawa, S. (2018). Balinese Papyrus Manuscript Image Segmentation Using DBSCAN Clustering Method. Journal of Theoretical and Applied Information Technology, XCVI(17), 5995-6005.

Xie, S., \& Tu, Z. (2015). Holistically-Nested Edge Detection University of California, San Diego. ICCV, 1395-1403. https://doi.org/10.1109/ICCV.2015.164

Xuan, L., \& Hong, Z. (2018). An improved canny edge detection algorithm. Proceedings of the IEEE International Conference on Software Engineering and Service Sciences, ICSESS, 2017-Novem, 275-278. https://doi.org/10.1109/ICSESS.2017.8342913

Yi, F., \& Moon, I. (2012). Image segmentation: A survey of graph-cut methods. 2012 International Conference on Systems and Informatics (ICSAI2012). https://doi.org/10.1109/ICSAI.2012.6223428 